日可赑

\title{
A CASE OF CONVERGENCE NYSTAGMUS
}

By

K. GOTO, J. SUZUKI, K. TOKUMASU E. SAKATA,

Y. MATUBA AND S. MOGI

From the Department of Oto-rhino-laryngology, Faculty of Medicine, University of Tokyo. (Director: Prof. I. Kirikae)

The Authors reported on convergence nystagmus in a 17 year old male. His chief complaints were bilateral tinnitus, bilateral hardness of hearing, and double vision. Craniotomy was performed by neurosurgeons. Postoperatively, he remained comatic and died 24 hours later.

Autopsy revealed a sharply defined, hen egg sized tumor (teratoblastoma), arising from the roof of the third ventricle and was found down-words the quadrigeminate palate.

Microscopically, the brain stem revealed lesions in the nuclei of the third nerve, superior olive nuclei and in the nuclei of the central grey matter.

Eye movement of the nystagmus was cinematophatographed in a $16 \mathrm{~mm}$ film.

\section{輻軼性眼振（Convergence Nystagmus）のl症例}

$$
\begin{aligned}
& \text { 東京大学医学部耳鼻咽喉科学教室（主任：切替一郎教授） } \\
& \text { 五 鳥 }
\end{aligned}
$$

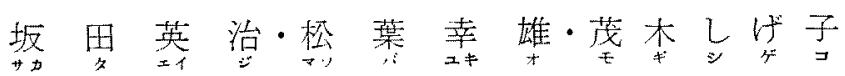

\section{はじめに}

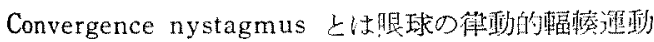
るいら。これが他の一般の腿振之異なる最大の点は, 腿 求の運動が非共扼性なることである。この腲振は Ferra

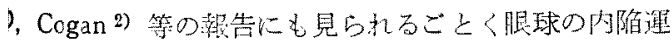
蚂ともならことが多いので Nystagmus convergenz etractoius とも呵ばれることがある、はなはだ稀れな

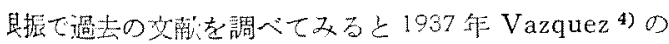

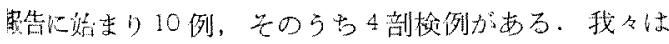

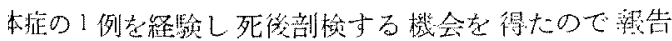

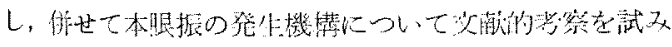
$t$.

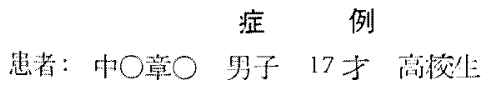 \\ 初晾：昭和34 年11月27日

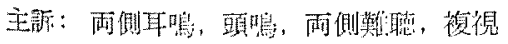

家族歴、既往嚁：特記すべきことはない。

現诚厢：昭和33 年暮, 複祝, 約 1 力月で自然に汌

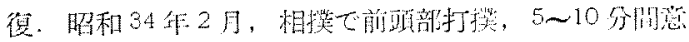

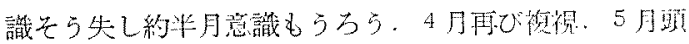

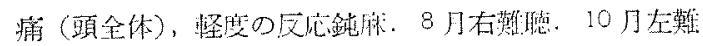

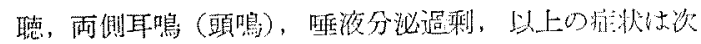

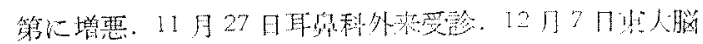
神経外科入入院。

(臨床换查所見)(12月1日)

1）一般神経学的所見：顔貌は表情少なく，マスク

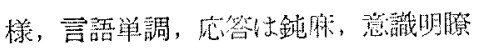

脳神経症候：腿症怾，視力 $V E=0.1(1.0 \%-2.0 \mathrm{D})$ ，

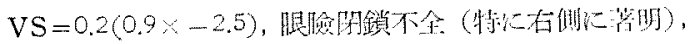
絶刘腷孔㤝㨁，自発腿振，Convergence nystagmus,

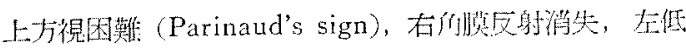

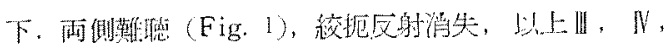

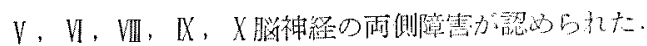

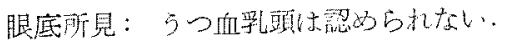

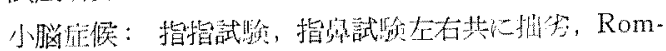

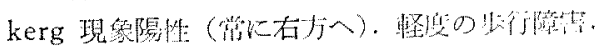


Fig. 1

12月9日 中○章○17才。

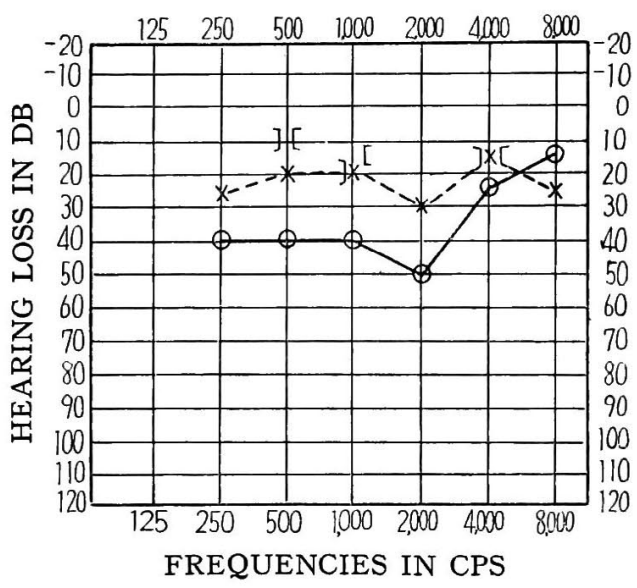

Fig. 2

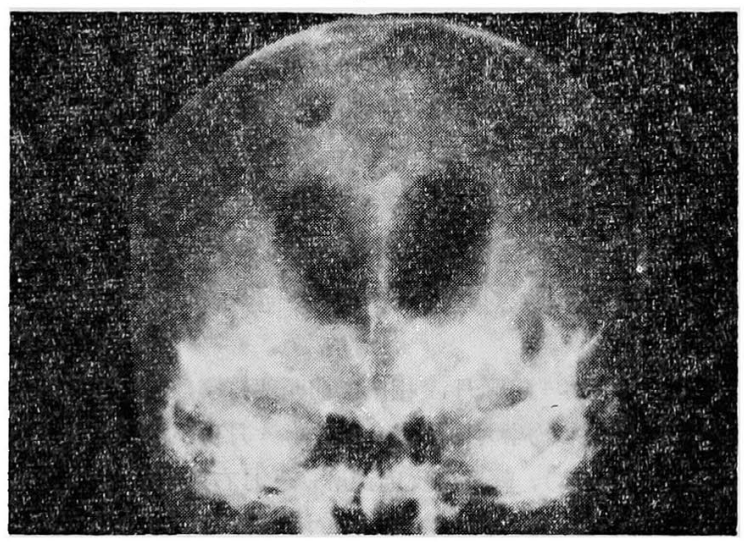

Fig. 3

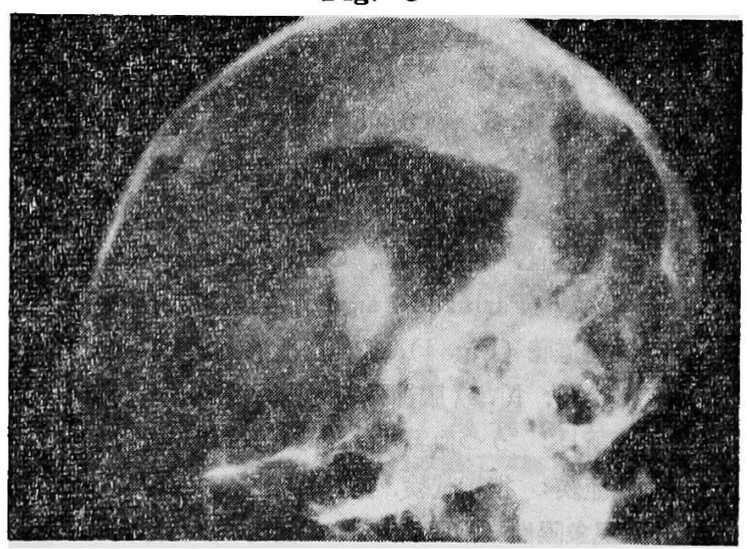

他の神経症候：右膝蓋腱反射妄進，右 Babinski 陽 性, 右下肢不全麻酸.

2) 骴液所見 (12月9日)：水样透明, 初圧 $270 \mathrm{~mm}$ $\mathrm{H}_{2} \mathrm{O}$ (坐位), 細胞数 44/3, Queckeustedt 陰性, Pandy $(+)$, Nonne-Apelt ( - )

3） $\mathrm{X}$ 線写真所見：気稱撮影火上り左右側脳室の著 明な拡大を認めた（Fig. 2,3). 他の X 線写真には異常 所見がない，

4) 耳嶴咽喉科学的所見 (12月1日)：鼓膜, 固有鼻 腔, 知頭には異常所見なし. 絞扼反射は消失.

聴覚㙨能：両側中等度難聴（Fig. 1)，応答不確実て 閾值測定困難，語音明瞭度右 $0 \%$ ，左 $2 \%$ （語音の了解 度が低下していることや, 反射的行動の遅鈍のため性と んど測定が不可能であつた).

前庭僟能：i）自発腿振検査, 裸眼では遠方視で自発 腿振なく，近点を注視させると著明な Convergence

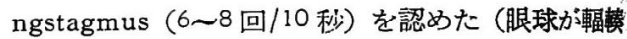
之共に内樎する傾向 Nystazmus retractorius 悓 られなかつた). Frenzel 腿鏡を装用すると，左向 きのごく軽度の 自発眼振（4〜6回/10秒）を認め た. 左下頭位で自発眼振の增強が見られた：ii）血 管性腿振，㾞孔性腿振は認められなかつた。 iii) 温度腿振, 回転腿振検查では, 左眼振方向優位性老 示した。 iv) 偏倚検查, Romkerg 現象, 足路梌 查, 遮眼書字検査ではいずれも右方偏倚傾向を誘好 た.

経過及び枟帰：昭和 34 年 12 月 19 日，脳神経外 科にて, 第 四脳室腫瘍の診断のもとは左後頭部開頊

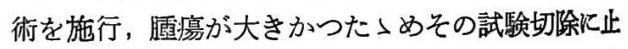
められた。 12 月 20 日 $41^{\circ} \mathrm{C}$ 発熟（視床下部刺激店 状か ?), 意識不明のま >死亡

\section{〔病理解剖所見】}

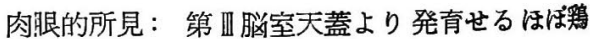
卵大の画瘴である.脳室壁に密着し松果体近傍より 発育し被包された硬い腫瘍で表面は結節状を呈して いる，一部のら臑を形成し部分的出血紧を認め大部 分は灰白色を呈している，右視床部及び腫場周辺部 の脳実質は萎縮している.中脳四丘体は腫瘍により 上方より圧迫され，その原形は認められずうすく 平板化している，下垂:体，頭蓋骨には変化はない (Fig. 4, 5).

組織学的所見. 四丘体上丘, 橋内耳神経入口部 上方及び下方横䉼の三部の組織塊をそれそれ10枚 


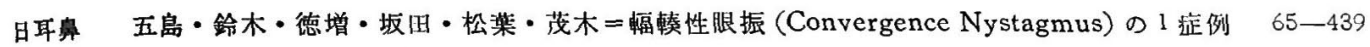

宛 15 20 $\mu$ の厚さの連続切片 標本を作り，神経細胞 及びその附酭線維を目的とした Luxol-Fast-Blue と Cresylviolet の重染色を施行した。との所見はｉ）四丘 体上丘の高さでは動眼神経核の一部(Edinger-Westphal

Fig. 4

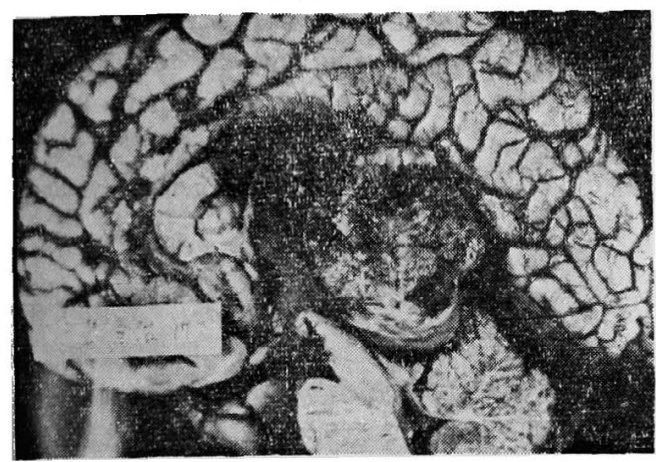

Fig. 5

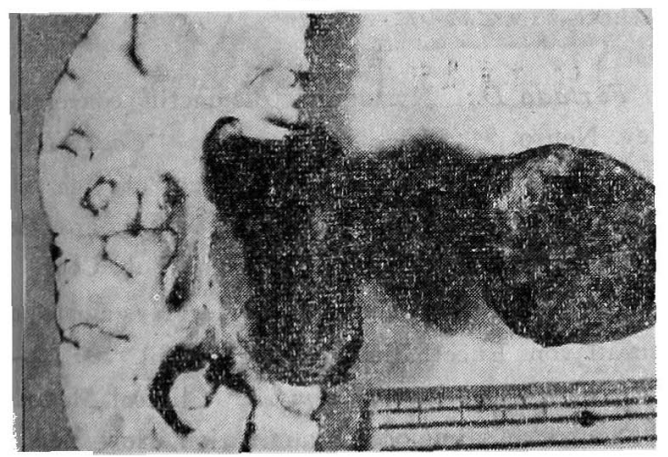

Fig. 6 Pathway of convergence and localization of lesions

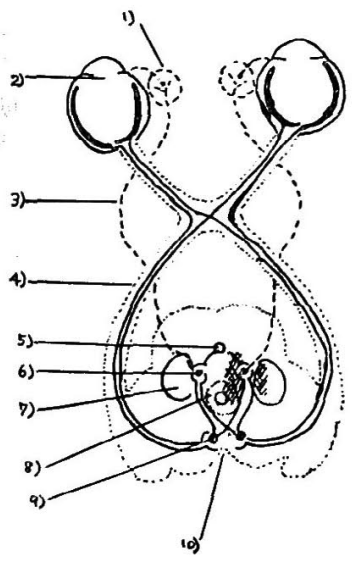

1) accenssory ganglion

2) eye ball

3) pathway of convergence reflex

4) optic tract

5) Perlia's nucleus

6) Edinger-Westphal nucleus

7) red nucleus

8) central grey matter

9) pretectal nucleus

10) pasterior commisur

localization of lesions
核)，中心兏白層の細胞数が減少している，また赤核細 胞の灙染しているところもある，ii）外転神経核の高さ では，外転神経核細胞の数的变化は認められないが一部 濃染している．上オリーブ核の内側及び外側には少しく 細胞数の減少しているところがある，前庭神経檬では， 外側核及び内側核ともに変化は認められない，梯形体の 細胞にも変化なく, 髉鞘にも変化は認めない(Fig. 6).

腫癁の組織学的所見：間質結合織中にのう尰が認め られ，円柱上皮，㻞平上皮細胞で被われている．間質に は粘液腫状組織, 解肉組織, 軟骨組織も存在し Teratoblastoma と諮断された（Fig. 7).

Fig. 7

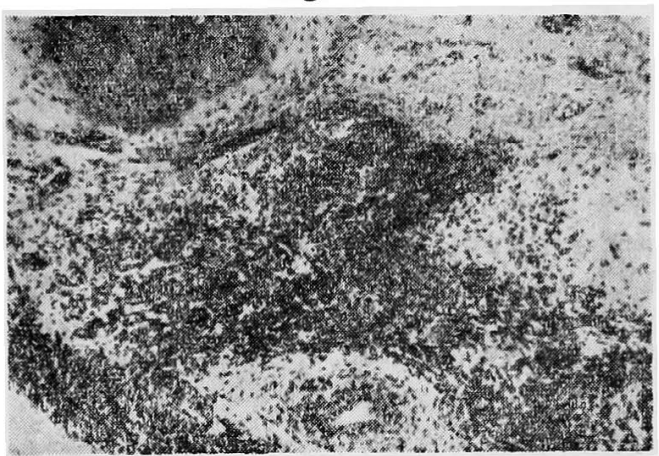

考察

本症例は Convergence ngstagmus のI 例で, 第任 脳室天蓋より発育せる巨大な Teratoblastoma に道伴し て見られたものである. Convergence nystagmus を過 去の文献について調べてみるとVazquez ${ }^{4)}$ (1937) に 始まり 10 例を見る。そのうち剖検例が 4 例ある. Furt. ado 1) は本症の 2 例剖検例を示し本眼振の発生機構につ いて論じている、乞の第1例では，洲発栍脳炎にみられ たもので，広站囲にわたる脳実質の炎症所見，特に脳 脚, 橋, 四丘体領域での炎症性細胞浸潤, 血管周囲炎が はなはだしかつたと述べている，第2例では，かなり大 きな松果体隀が，中脳水道周辺招よび四丘体領琙に慢性 の质迫を加え，ひいては脳脚部にまで抎がつた障密を与 光、脳脚部では動腿神絽核をはじめ他の神経細胞群の变 性をきたしたと述べている．この 2 例より本腿振の発現 は脳脚，四丘体，中脳水道周辺に限局された炎症性また は生迫性障害によるものとしている．Cogan 2)（1959） は本腿振の 6 例を示し 1 例の剖検例を得ている。すなお 号第四脳室の巨大な松果体婳瘍で，四丘体を强く圧迫し ていたもので Convergence nystagmus と共に眼球の 
内陷連動 (Nystagmus retractorins) も認妨らたとし ている.他の5 例は，隐床所見より各々次のごとく診断 している. i) 中脳ことに中脳前部 (anteriormidbrain) の血管障害，ii）畄䭪虏による中脳前部の圧迫（retra. ction type), iii) 中脳上方部の乏血状態, iv) 視床か ら中脳へかけての助管障篦，v）中脳前部の血管性病 変. 結諭として本䏹振の発現は中脳前部 (anterior midbrain）の障害に由来するものであると述べている，中 脳前部 (anterior midbrain) が那剖学的にどの部分を 与めているのか詳しい記載がなされていない点は, 租織 学的にな打㐬分検討される余排があるものと考古られ る. Cogan 2) は本腿振の発現が眼球腷棂の緊張性支配,

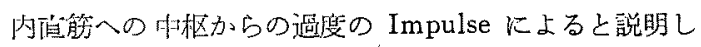
ている.以上3例の剖検例で怯，脳脚部血管周围へのび ま儿珄細胞浸潤，中脑動眼神経核，Perlia 核，中腈水 道周辺，中心灭白筫などの細胞变性を繠めている。

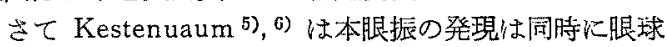
の内陷運動を示すことが多く，同時に Parinaud's sign を示していることが多くこれを Paraaquaductal syndrome と呼しでいる. 本腿振の発現は中脳水道周辺の病 栄猃楽上重要なものであるとしている。これまで蛝告の あつた10 例中 2 例沉この内樎運動を伴なつた retraction type みている. 我々の症例ではこの傾向はなか つた.

Perlia, Bruce ${ }^{8)}$ (1889) に上り扔の和の独自に癹表さ

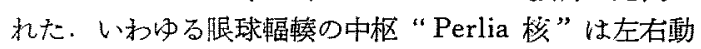
跟神経核の中間に存在する渾動神経細胞群である. 一方 Warwick ${ }^{8)}$ (1955) は比較解剖学的研究により“Perlia 核”の存を否定しているが現在では一応この核の存 在が認められている (Duke-Edler ${ }^{9)}$, Adler ${ }^{10)}$, Kestenbaum ${ }^{6}$, Cogan $\left.{ }^{2)}\right)$.

以上のごとく病理解剖学的には本腿振の発生原因を, 中脳水道周辺, 四丘体, 動腿神経核 (Perlia 核を含む) の病変に求めることができるが本腿振の発生機構に関し ては多くの要因が関与するためな和充分な説明がなされ ていない。

Furtado, Cogan は Bender 7) (1955) に上り発菱さ れた“eye centering system”にもとずいて本腿振の 発生機構を説明している. “ eye contering system”と いう仮説的機䊈は，大脳皮貿を含を脳幹部にわたる広い 領覀が関与している。注規線を中心位に同けさせるある 複䧴な機橴があると同様に，その注視線の中心位から離 れる機構がある.この機構の一部分の障害により，两機 楧の不均衡をきたし本腿振を発生させるものであると説 明しているがまだ仮説的なものである．以上を要約すれ ば Convergence nystgmus の発生機構は, 器啠的には, 中脳水道周辺, 四丘体, 動职神経核周辺の病变飞求如, 機能的には“eye centering system”の一部分の不均 衡に艺の原因を求め得るすのである。

我々の症例に括いては，内眼的にも組織学的飞も中腷 四丘体周辺では動腿神経核の一部, 中脳水道周辺中心灰

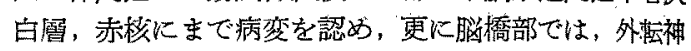
経核，上方リーブ核にまで病変を見出している，我々の 症例に和ける眼振の発現は, 器質的には上記のことく, 機能的には “eye centering system”の一部の不均衡 及び外轱神経への中枢からの遗度の Impulse に求める ことができよう、本腿振の模様は $16 \mathrm{~mm}$ 䁖画として保 存してある。な技本症例は，Convergence nystagmus としては本邦初めての剖検例である。

\section{まとめ}

17 才, 男子, 高洨生, 両耳鳴 (頭鸣), 複視を主訴と

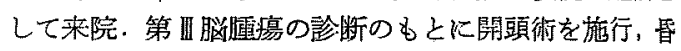
睡状䈍のま〉死亡. 剖検の結果第 $\mathbb{1}$ 腷重天蓋より発生し たはよ゙鵎卵大の腫湯でテラスブラストーマと診断され た.腫瘍は中脳四丘体，中畄水道を強く王迫して招り， 病理組織学的には動腿神経核の一部, 中心灰白筫, 外标 神経校に病变を認めた。

\section{文献}

1) Furtado D.: Nystagmus disjonctiff convergent Rev. Neuro. 94: 335 350, 1956. 2) Cogan D.G.: Convergence Nystagmus AMA. Arch. of Oph. 62: 295 299, 1959. 3) Cogan D.G.: Neurology of the ocular mucle Ill. Charles C. Thomas Pub. Comp.

4) Vazquez B.A.: Konvergierender Nystagmus in einfall von Encethalitis lethargica Zbl. 30:264 267, 1938. 5) Kestenbaum A.: Clinical Methods of Neuroophthalmalogic Examination, New York, Grune \& Stratton Inc. 1948. 6) Kestenbaum A. Advanced Ophthalmology 7: 270 272, $1956 . \quad 7)$ Bender M.B.: The eye-centering System Arch. Neuro. \& Psych. 73:685 699, 1955. 8) Warrwick: The so called nucleus of convergence Brain 78:92 $\sim 114,1955$. 9) Duke-Edler: Textbook of Ophthalmology $4: 4201,1950$. 10) Adler F.H.: Phys. iology of eye, clinical application. Masley Comp. 361 〜371，1953.11）切替，佐菲：中腷性難㯖をきたし

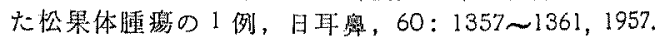

本症例の検索沈たり御指導，御校閲を瑒的 つた切替一郎教授に心から感謝の意を表わした い.な打病理組䄉㛟查を御指遒下さつた東京医 幽大万年甫博士ならびに本症例の模索につき乘

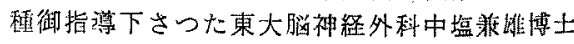
に心から感謝の意を表わしたい。

（惊稿到着 $=$ 昭和 36.11 .6 日） 